\title{
Measles outbreak during the COVID-19 pandemic in Mexico
}

\author{
Fortino Solórzano-Santos ${ }^{1 *}$, Juan Garduño-Espinoza², and Onofre Muñoz-Hernández ${ }^{3}$ \\ ${ }^{1}$ Unidad de Investigación en Enfermedades Infecciosas, Hospital Infantil de México Federico Gómez; ${ }^{2}$ Dirección de Investigación, Hospital Infantil \\ de México Federico Gómez; ${ }^{3}$ Comisión Nacional de Arbitraje Médico, Secretaría de Salud. Mexico City, Mexico
}

\begin{abstract}
Measles is an exanthematous disease caused by a virus of the Morbillivirus genus. On February 23, 2020, the exanthema began in the first confirmed case of measles this year. At the same time, on February 28, 2020, the first case of the new coronavirus disease (COVID-19) was confirmed. Up to June 6, 2020, 176 measles cases have been confirmed: 137 in Mexico City, 37 in the state of Mexico, and two in the state of Campeche. In Mexico City, municipalities with more cases were Gustavo A. Madero, Miguel Hidalgo, and Iztapalapa; in the State of Mexico were Ecatepec, Tlalnepantla, and Netzahualcoyotl; in Campeche, there are only two cases reported. On the other hand, 7,065,133 cases of COVID-19 have been registered worldwide with a global case fatality rate of 5.7\%. In Mexico, there have been 113,619 confirmed cases and 13,511 deaths, while in Mexico City, there have been 30,223 cases and 3062 deaths. Iztapalapa and Gustavo A. Madero are the locations with more cases reported. Hence, a campaign of social distancing started as part of the strategies to control the spread of the infection. The potential threat is that as social confinement measures are relaxed and mobility is initiated, both viruses could continue to spread. It is expected that due to the time that has passed since the last reported measles case, control of this disease will be achieved.
\end{abstract}

Key words: Measles. Coronavirus disease-19. Vaccination.

\section{Brote de sarampión durante la pandemia de COVID-19 en México}

\section{Resumen}

El sarampión es una enfermedad exantemática causada por un virus del género Morbilivirus. El 23 de febrero de 2020 inició el exantema en el primer caso confirmado en este año; el 28 de febrero de 2020 se confirmó el primer caso de enfermedad por un nuevo coronavirus (COVID-19). Hasta el 6 de junio de 2020 se han confirmado 176 casos de sarampión: 137 en la Ciudad de México, 37 en el Estado de México y 2 en Campeche. En la Ciudad de México, las alcaldías con más casos son Gustavo A. Madero, Miguel Hidalgo e Iztapalapa; en el Estado de México, la mayoría de los casos se presentan en Ecatepec, Tlalnepantla y Netzahualcóyotl; en el estado de Campeche solo se han reportado dos casos. Hasta el 6 de junio de 2020 se habían registrado en todo el mundo 7,065,33 casos de COVID-19, con una letalidad global del 5.7\%. En México se han

\section{Correspondence:}

${ }^{*}$ Fortino Solórzano Santos

E-mail: solorzanof056@gmail.com

Available online: 01-09-2020

Date of reception: 20-06-2020

Date of acceptance: 23-06-2020

DOI: 10.24875/BMHIM.20000173
Bol Med Hosp Infant Mex. 2020;77(5):282-286

www.bmhim.com 1665-1146/@ 2020 Hospital Infantil de México Federico Gómez. Published by Permanyer. This is an open access article under the CC BY-NC-ND license (http://creativecommons.org/licenses/by-nc-nd/4.0/). 
presentado 113,619 casos confirmados y 13,511 muertes; de ellos, 30,223 casos y 3,062 muertes en la Ciudad de México, siendo las alcaldías de Iztapalapa y Gustavo A. Madero las que han tenido el mayor número de casos. Como parte de las estrategias para controlar la diseminación de la infección, se decidió iniciar la campaña de distanciamiento social. La amenaza latente es que, al disminuir las medidas de confinamiento social e iniciar la movilidad paulatina, podrían continuar diseminándose ambos virus. Se espera que debido al tiempo transcurrido desde el último caso de sarampión reportado se logre el control de esta enfermedad.

Palabras clave: Sarampión. COVID-19. Vacunación.

\section{Introduction}

Measles is an exanthematous disease caused by a virus of the genus Morbillivirus, which most often affects children, although, in places with low vaccination coverage, it can affect any age group. It clinically presents with fever, rhinitis, conjunctivitis, cough, and pathognomonic enanthem (Koplik's spots), with the subsequent appearance of a centrifugal maculopapular rash.

In Mexico, the measles vaccine was introduced in 1973. However, during the period from 1973 to 1985 , vaccination programs targeted populations with more than 1500 inhabitants, leaving an annual cohort of about 1 million newborns without the benefit of vaccination.

Until 1989, measles vaccine coverage was about $50 \%$, with adequate coverage in populations with health services and insufficient coverage in rural and periurban areas'.

A measles pandemic occurred in 1989, which spanned the Americas, including Mexico; the pandemic peaked in 1990 with 68,782 reported cases. Although most cases occurred in children aged 5-14, the highest incidence occurred in children under 1 year of age; measles caused 5988 deaths that year. In 1991, the measles pandemic decreased; 5077 cases were reported, and mortality dropped to 97 cases. In 1992, a house-to-house vaccination campaign was conducted for susceptible children. Based on the Pan American Health Organization (PAHO) guidelines, strategies were implemented in Mexico for the elimination of measles: (1) increasing vaccination coverage in children, (2) carrying out aggressive control measures in response to outbreaks; and (3) developing a specific, high-quality surveillance system; these strategies have been maintained to date.

Between 1996 and 2019, there were no local measles cases in the country. Through the epidemiological surveillance system, it has been possible to detect outbreaks imported from different countries. In 2016, the Region of the Americas was declared free of measles by the $\mathrm{WHO}$ and $\mathrm{PAHO}^{2}$. However, measles outbreaks have continued in several regions of the world, and the migration of infected individuals from these countries poses a latent risk for the reintroduction of the disease.

The WHO/PAHO reported that in 2019, there were 20,554 cases in Latin America, from January 1, 2020, to February 22, 2020, 393 cases were documented. From December 13, 2019, to January 24, 2020, there was $29 \%$ increase in confirmed measles cases globally ${ }^{3}$.

The Organization for Economic Cooperation and Development ${ }^{4}$ and $\mathrm{WHO} / \mathrm{PAHO}^{5}$ show that vaccination coverage in Mexico has declined since 2013, ranging from 83 to $89 \%$ (average $=87 \%$ ) from 2013 to 2018 , with a greater decline in 2017 (79\%).

\section{Measles 2020 outbreak}

The first confirmed case of measles was an 8-yearold female patient who started her symptoms on February 23, 2020. From this case, two other previous cases with exanthema were identified (February 12 and 13). By June 6, 2020, 176 cases of measles had been confirmed, distributed as follows: 137 cases in Mexico City; 37 in the State of Mexico and 2 in the State of Campeche. In Mexico City, the municipalities, with most cases, were Gustavo A. Madero, Miguel Hidalgo, and Iztapalapa, while in the State of Mexico were Ecatepec, Tlalnepantla, and Netzahualcóyotl (Table 1). In Champotón, Campeche, eight suspicious cases were reported; two were confirmed. Initially, it was considered that the largest number of initial cases in the municipality of Gustavo A. Madero was related to an outbreak in the Reclusorio Norte Prison.

In this outbreak, measles has been predominant among males (57\%). The distribution by age group is shown in figure 1 , where a high frequency in patients over 20 years old (49\%) stands out, and it is worrying that $11.3 \%$ were under 1 year old. A total of $19 \%$ of confirmed cases reported receiving the measles 


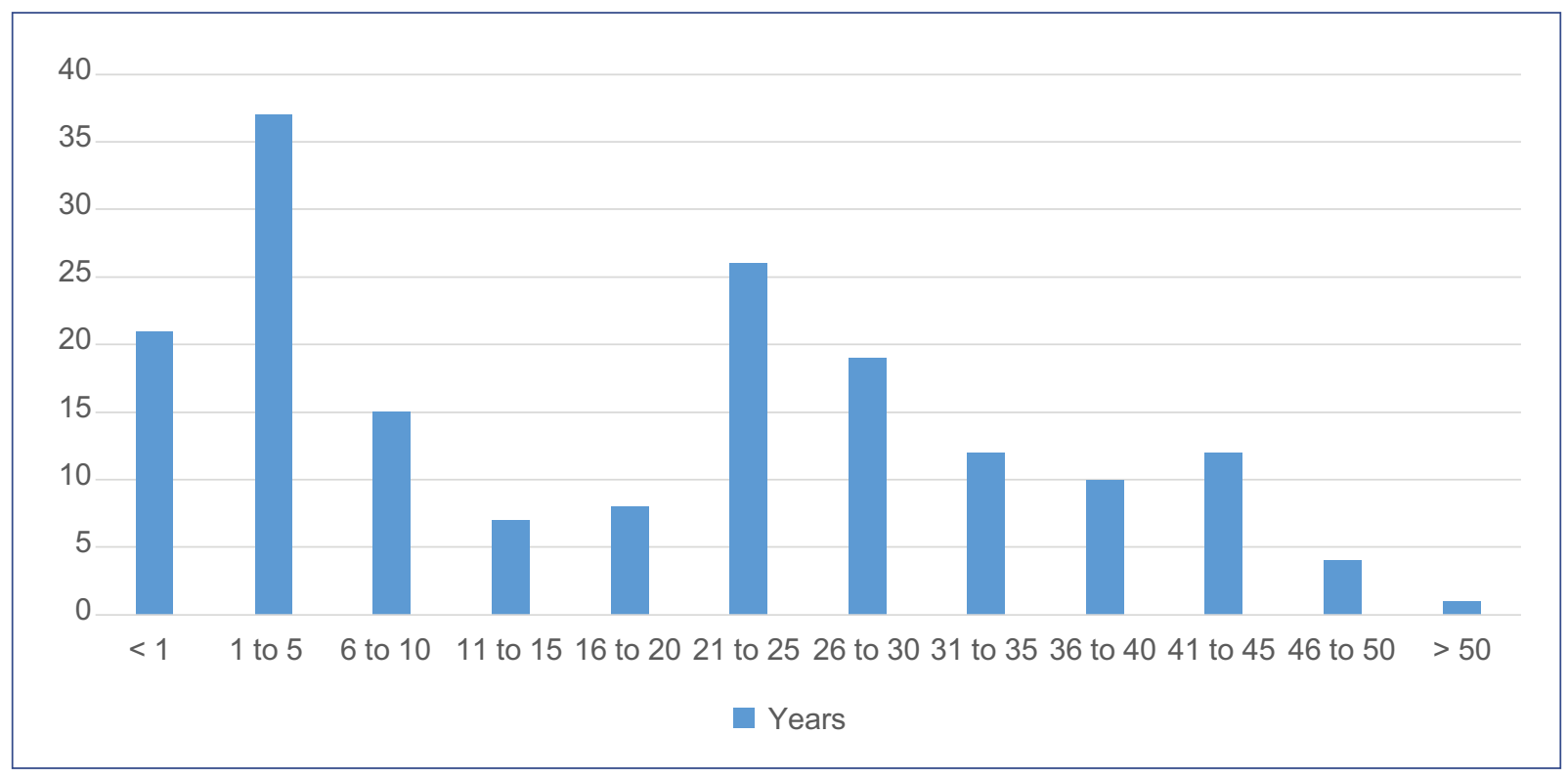

Figure 1. Measles in Mexico by June 6, 2020.

Table 1. Distribution of confirmed cases of measles in Mexico

\begin{tabular}{|l|c|l|c|}
\hline $\begin{array}{l}\text { Mexico City } \\
\text { (municipalities) }\end{array}$ & $\begin{array}{c}\text { Confirmed } \\
\text { cases }\end{array}$ & $\begin{array}{l}\text { States } \\
\text { (municipalities) }\end{array}$ & $\begin{array}{c}\text { Confirmed } \\
\text { cases }\end{array}$ \\
\hline Gustavo A. Madero & 75 & State of Mexico & \\
\hline Miguel Hidalgo & 17 & Ecatepec & 12 \\
\hline Iztapalapa & 10 & Tlalnepantla & 10 \\
\hline Cuajimalpa & 08 & Netzahualcóyotl & 4 \\
\hline Álvaro Obregón & 07 & Toluca & 2 \\
\hline Cuauhtémoc & 05 & Tecámac & 2 \\
\hline Xochimilco & 04 & Zinacantepec & 1 \\
\hline Coyoacán & 03 & $\begin{array}{l}\text { Atizapán de } \\
\text { Zaragoza }\end{array}$ & 1 \\
\hline Tláhuac & 02 & Cuautitlán & 1 \\
\hline Tlalpan & 02 & Chimalhuacán & 1 \\
\hline Iztacalco & 01 & Naucalpan & 1 \\
\hline Milpa Alta & 01 & Zumpango & 1 \\
\hline Azcapotzalco & 01 & Huehuetoca & 1 \\
\hline Venustiano Carranza & 01 & Campeche & 2 \\
\hline Total & 137 & Champotón & 39 \\
\hline
\end{tabular}

vaccine $^{6}$ (at least one dose). In 170/176, the diagnosis was made by polymerase chain reaction; the other 6 had a positive serological test for immunoglobulin $\mathrm{M}$. Genotyping analysis done by the Instituto Nacional de Referencia Epidemiológica confirmed that the cases corresponded to measles genotype D8 and lineage MVs/Gir Somnath.IND/42.16 .

\section{Coronavirus disease 19 (COVID-19)}

On February 28, 2020, the first case of COVID-19 was confirmed in Mexico City. COVID-19 was the name given to the disease caused by the severe acute respiratory syndrome coronavirus 2 virus, a new coronavirus that spreads from Wuhan, China, to the rest of the world and has now produced a major pandemic. As of June $6,2020,7,065,133$ cases have been reported worldwide, with a global case fatality rate of $5.7 \%$. In Mexico, there have been 113,619 confirmed cases and 13,511 deaths. In particular, in Mexico City, there have been 30,223 cases and 3062 deaths, with the municipalities of Iztapalapa and Gustavo A. Madero having the highest number of cases (5680 and 3850, respectively); together with the municipalities of Tlalpan (2166 cases), Álvaro Obregón (1974 cases), Xochimilco (1894 cases), and Miguel Hidalgo (1175 cases), they occupy the first places 
in confirmed cases $^{8}$. As part of the strategies to control the spread of the infection, it was decided to start the social distancing campaign called Jornada Nacional de Sana Distancia, achieving confinement of about $60 \%$ of the population in their homes. There has been variability in terms of population mobility, according to the states and municipalities of the country.

\section{Discussion}

Almost coincidentally, there are two public health problems in our country: first, the COVID-19 pandemic and second, a measles outbreak, both diseases with a high degree of transmissibility.

Until 2019, small outbreaks of measles had been adequately controlled in Mexico. Virtually all cases were considered as imported or by direct exposure to imported cases and were limited through epidemiological containment.

It is a warning for our health system that, despite the strategies of social distancing, the presentation of successive cases of measles in different municipalities of Mexico City has continued and has extended to the State of Mexico and to populations increasingly distant from the urban area and even to the state of Campeche. Concerning Mexico City, two of the municipalities with the highest number of measles cases (Gustavo A. Madero and Iztapalapa) are the ones with the highest number of COVID-19 cases, which probably suggests a lack of adherence to the Sana Distancia indications; another three municipalities (Coyoacán, Cuauhtémoc, and Miguel Hidalgo) are also among those with the highest number of COVID-19 cases.

The latent threat is that as social confinement measures are reduced, and mobility increases, both viruses may continue to spread. The gradual increase in measles cases may exacerbate problems of care at different levels of health services. It is encouraging that so far, the beginning of the exanthema of the last measles case was reported on May 1, and 4 weeks have passed without the appearance of a new case.

The behavior of this measles outbreak has revealed that there is a large group of susceptible individuals in the population. A high percentage of cases (33.7\%) were children under 5 years of age. Most of them had no previous vaccination, reflecting a core population that should necessarily have been vaccinated, as it is an essential part of the National Immunization Record. The group from 6 to 20 years old reflects those children who did not receive a second dose, which has been a strategy implemented in our country for several years.
The 21-40 age group (39\%) represents those who were not vaccinated or only received one dose and lost the protective antibody level. The group over 41 years old $(10 \%)$ raises several questions, as most of them should have been exposed to the wild virus and faced at least the 1990 epidemic.

Vaccination coverage has gradually declined in recent years due to various factors, including a temporary shortage of the vaccine, coupled with the population migration crisis from Central and South America that our country has faced. These factors have contributed to a susceptible population that has been gradually accumulating. Furthermore, the involvement of anti-vaccine groups at international level has enabled the reemergence of measles in several countries and, consequently, the recirculation of the virus.

The above issues could seriously affect Mexico and other Latin American countries with the resurgence of measles. This would end the decades-long effort to control and eradicate measles in the Americas.

During the COVID-19 pandemic in our country, the national vaccination program has not been suspended; however, compliance with stay home guidelines meant that many mothers did not take their children for vaccination. Promotion and invitation to the population to return to the regularization of vaccination schemes are required. The Dirección General de Epidemiología (General Office of Epidemiology) issued eight objectives to control the measles outbreak during the COVID19 pandemic, which should be given greater publicity to prevent an increase in cases of this disease in our country ${ }^{9}$.

\section{Ethical disclosures}

Protection of human and animal subjects. The authors declare that no experiments were performed on humans or animals for this study.

Confidentiality of data. The authors declare that they have followed the protocols of their work center on the publication of patient data.

Right to privacy and informed consent. The authors have obtained the written informed consent of the patients or subjects mentioned in the article. The corresponding author is in possession of this document.

\section{Conflicts of interest}

The authors declare that they have no conflicts of interest. 


\section{Funding}

None.

\section{References}

1. Santos JI, Nakamura MA, Veras-Godoy M, Kuri P, Alvarez-Lucas C Tapia-Conyer R. Measles in Mexico, 1941-2001: interruption of endemic transmission and lessons learned. J Infect Dis. 2004;189:S243-50.

2. Pan American Health Organization. Region of the Americas is Declared Free of measles. Washington, DC.: Pan American Health Organization. Available from: https://www.paho.org/hq/index.php?option=com content\&view=article\&id=12528:region-americas-declared-free-measles\&ltemi$d=1926$ \&lang=en

3. Organización Panamericana de la Salud. Washington, DC: Actualización Epidemiológica Sarampión. Available from: https://www.paho.org/hq/ index.php?option=com_docman\&view=download\&category_slug=saram pion-2183\&alias $=51810-28-$ de-febrero-de-2020-sarampion-ac- tualizacion-epidemiologica-1\&ltemid=270\&lang=es). [Last accessed on 2020 Feb 28].

4. Organization for Economic Cooperation and Development. Paris: Child Vaccination Rates. Available from: https://www.oecd-ilibrary.org/social-issues-migration-health/child-vaccination-rates/indicator/english_ b23c7d13-en.

5. Organización Panamericana de la Salud. Washington, DC: Inmunización en las Américas. Resumen; 2018. Available from: https://www.paho.org/ es/node/59921.

6. Secretaria de Salud. México: Boletín Informativo No. 8 Sobre Situación Actual Del Brote Por Sarampión, Mexico; 2020. Available from: http:/ www.ssm.gob.mx/portal/sarampion/descargables/boletines/Boletin $\% 20$ 8\%20SARAMPION_29\%2005\%202020.pdf.

7. Gobierno de México. Mexico: Tabla Resumen Casos de Sarampión 2020. Available from: https://www.gob.mx/salud/documentos/casos-confirmados-por-sarampion-2020.

8. Gobierno de México. Mexico: Covid-19 México Datos. Available from: https://www.coronavirus.gob.mx/datos.

9. Gobierno de México. Mexico: Plan de Respuesta Rápida Para el Control Del Brote de Sarampión. Abril; 2020. Available from: https://www.gob.mx/ salud/censia/documentos/guia-sarampion-10abril-2020 